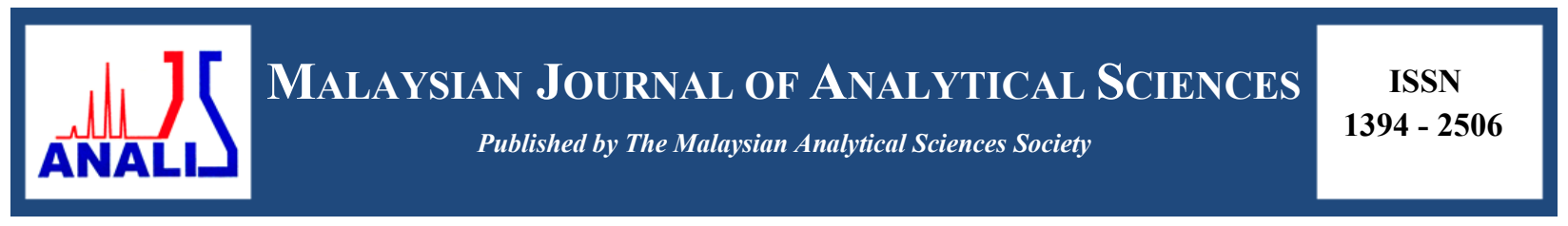

\title{
CHARACTERIZATION OF ACTIVATED CARBON USING CHEMICAL ACTIVATION VIA MICROWAVE ULTRASONIC SYSTEM
}

\section{(Pencirian Karbon Teraktif Menggunakan Sistem Pengaktifan Kimia Melalui Ketuhar Gelombang Ultrasonik)}

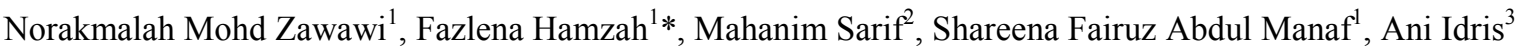 \\ ${ }^{I}$ Biocatalysis \& Biobased Material Research Group, Green Technology and Sustainable Development Research Community, \\ Faculty of Chemical Engineering, \\ Universiti Teknologi MARA, 40450 Shah Alam, Selangor, Malaysia \\ ${ }^{2}$ Wood Chemistry and Protection Program, Forest Product Division, \\ Forest Research Institute Malaysia (FRIM),52109 Kepong, Malaysia \\ ${ }^{3}$ Faculty of Chemical Engineering, \\ Universiti Teknologi Malaysia, 81310 Skudai, Johor, Malaysia \\ *Corresponding author: fazlena@salam.uitm.edu.my
}

Received: 21 October 2015; Accepted: 14 June 2016

\begin{abstract}
Higher adsorption capacities of activated carbon (AC) can be evaluate according to pore volume, porosity and surface area. AC with higher pore volume, porosity and surface area desired in the present study in order to enhance the properties of AC supercapacitor. Thus, the present studies focus on the chemical activation process to increase the characterization of AC. The study was using bamboo waste as a precursor and the activation process was conducted using microwave ultrasonic system. The chemical agent used during the process was $\mathrm{KOH}$ and $\mathrm{H}_{2} \mathrm{SO}_{4}$. Microwave activation was conducted at intensity $100 \mathrm{~W}$ and 300 $\mathrm{W}$ for $30 \mathrm{~min}$ and sonication frequency was constantly set at $200 \mathrm{~Hz}$ for $60 \mathrm{~min}$. The sample was carbonized at temperature of $400{ }^{\circ} \mathrm{C}$ and $800{ }^{\circ} \mathrm{C}$ using furnace for 2 hours. Then, AC was characterized for surface area using BET analysis and functioning group using FTIR analysis. The results shown the carboxyl, aliphatic, aromatic and phenolic hydroxyl group are present on raw bamboo while new functional group such as alkyl halide and some of some weak bands appeared which analogous with out of plane bending mode of the $\mathrm{C}-\mathrm{H}$ or O-H group occur for AC. Active surface area and total pore volume of AC supercapacitor in $5 \mathrm{M}$ of concentration for $\mathrm{H}_{2} \mathrm{SO}_{4}$ and $\mathrm{KOH}$ corresponded to $1167 \mathrm{~m}^{2} / \mathrm{g}, 0.724 \mathrm{~cm}^{3} / \mathrm{g}, 740.10 \mathrm{~m}^{2} / \mathrm{g}, 0.462 \mathrm{~cm}^{3} / \mathrm{g}$, respectively.
\end{abstract}

Keywords: supercapacitor, microwave-ultrasonic, activation, chemical, carbonization

\section{Abstrak}

Kapasiti penjerapan yang tinggi pada karbon teraktif boleh dinilai mengikut isipadu liang, keliangan dan luas permukaan. Keaktifan karbon dengan isi padu liang yang tinggi, tahap keliangan yang besar dan luas permukaan yang tinggi amat dikehendaki di dalam kajian ini bagi meningkatkan sifat-sifat keaktifan karbon superkapasitor. Oleh itu, kajian ini memberi tumpuan kepada proses pengaktifan kimia untuk meningkatkan pencirian yang diperlukan dalam karbon aktif. Kajian ini telah menggunakan sisa buluh sebagai pelopor dan proses pengaktifan telah dijalankan menggunakan sistem ultrasonik-gelombang mikro. Agen kimia yang digunakan semasa proses pengaktifan adalah $\mathrm{KOH}$ dan $\mathrm{H}_{2} \mathrm{SO}_{4}$. Pengaktifan gelombang ketuhar telah digunakan pada intensiti $100 \mathrm{~W}$ dan $300 \mathrm{~W}$ selama $30 \mathrm{~min}$ dan kekerapan sonikasi telah ditetapkan pada $200 \mathrm{~Hz}$ selama $60 \mathrm{~min}$. Sampel telah dikarbonisasi pada suhu $400{ }^{\circ} \mathrm{C}$ dan $800^{\circ} \mathrm{C}$ mengunakan relau selama 2 jam. Kemudian, karbon aktif dikelaskan bagi mendapatkan luas permukaan dengan menggunakan analisis BET dan kumpulan berfungsi pula menggunakan analisis FTIR. Keputusan menunjukkan karboksil aliphatik, aromatik dan kumpulan fenolik hidrosil hadir pada bahan asas buluh manakala kumpulan berfungsi baharu seperti alkil halida dan beberapa kumpulan yang lemah muncul dimana serupa dengan lenturan mod bagi C-H atau O-H yang terhasil pada karbon aktif. Kawasan permukaan yang aktif dan jumlah isipadu liang 
karbon aktif superkasitor pada kepekatan $5 \mathrm{M}$ untuk $\mathrm{H}_{2} \mathrm{SO}_{4}$ and $\mathrm{KOH}$ sepadan mengikut aturan $1167 \mathrm{~m}^{2} / \mathrm{g}, 0.724 \mathrm{~cm}^{3} / \mathrm{g}, 740.10$ $\mathrm{m}^{2} / \mathrm{g}, 0.462 \mathrm{~cm}^{3} / \mathrm{g}$.

Kata kunci: superkapasitor, gelombang mikro-ultrasonik, pengaktifan, bahan kimia, karbonisasi

\section{Introduction}

Activated carbon (AC) is widely use as catalyst, catalyst support and adsorbent for the removal of pollutant order from liquid to gases and for purification or recovery of chemicals [1]. A wide range of carbonaceous materials such as agricultural wastes or industrial wastes, coconut shell, coal and wood can be used as activated carbon precursor. In industrial practice, coal and coconut shell are two major sources for the production of activated carbon [2]. Bamboo, one of the lignocellulosic resources is a potential precursor for activated carbon due to its flexible, efficient and economical materials [3]. Bamboo has a high volatile matter and low of ash content that required in $\mathrm{AC}$ processing with high adsorption capacities are related to property of pore volume, porosity and surface area. Current approach in AC processing gave AC with a small of surface area, limited power intensity and energy capacity and low of porosity [4]. In order to overcome these problems, chemical activation and microwave ultrasonic activation has been introduced to enlarge the surface area, extensive the power intensity and energy capacity and enhance the porosity of AC.

Activated carbon works by the process of adsorption. Adsorption is a process when one material adheres to the surface of another material by means of physical or chemical attraction between the materials. There are two processes involves in development the formation of $\mathrm{AC}$ which are activation and carbonization processes. In activation, there are two types of method in order to produce activated carbon from carbonaceous material which is chemical and physical method. Physical activation procedure required two step of process which are carbonization and followed by activation using steam, oxygen or carbon dioxide as an activation agent while chemical activation procedure involves a single stage by using chemical as activating agent such as zinc chloride, potassium hydroxide, phosphoric acid and others [5]. Chemical procedure takes a few of advantage than physical method which has higher carbon yield and better developed of pore structure [6].

Thus, in the present study, bamboo was prepared for AC by using different of chemical activation agent which is $\mathrm{KOH}$ and $\mathrm{H}_{2} \mathrm{SO}_{4}$ under microwave ultrasonic radiation for activation process and continues with a single step of carbonization process at different temperature. The aim of this study is to characterize the characteristics of bamboo properties as activated carbon with chemical activation in microwave-ultrasonic activation.

\section{Materials}

\section{Materials and Methods}

The chemicals used in this study are sulphuric acid $\left(\mathrm{H}_{2} \mathrm{SO}_{4}\right)$ and potassium hydroxide $(\mathrm{KOH})$ purchased from $\mathrm{R} \& \mathrm{M}$ Chemical, Inc. Both chemicals were analytical grade.

\section{Preparation of activated carbon}

The precursor for activated carbon was residual bamboo obtained from Forest Research Institute Malaysia (FRIM). A total $50 \mathrm{~g}$ of dry bamboo was placed into crucible and the chemical agent, $\mathrm{KOH}$ or $\mathrm{H}_{2} \mathrm{SO}_{4}$ was added into the sample with ratio 1:1. Then, the sample undergoes microwave activation with different energy power for $2 \mathrm{hr}$. Activate sample was cooled and washed with distilled water until pH 6 to 7 . The sample was dried in oven at $110^{\circ} \mathrm{C}$ for 24 hours and stored in desiccator before undergoes carbonization process. Next, the sample was carbonized in the Vermont Furnace (Carbolite, Keison) under the flow of $150 \mathrm{~cm}^{3} / \mathrm{min}$ nitrogen for 2 hours. After carbonization process, the activated carbon was cooled to ambient temperature for further analysis. Parameter used in the present study is stated in Table 1. 
Table 1. Parameter used in Microwave-ultrasonic system with chemical agent

\begin{tabular}{|c|c|c|}
\hline Sample & Experiment Procedure & Chemical Activating Agent \\
\hline AC_OH_8 & Ultrasonic-MW (300W)-Carbonize $\left(800^{\circ} \mathrm{C}\right)$ & Base - KOH \\
\hline AC_OH_4 & Ultrasonic-MW (300W)-Carbonize $\left(400^{\circ} \mathrm{C}\right)$ & Base - KOH \\
\hline AC_H_8 & Ultrasonic-MW (300W)-Carbonize $\left(800^{\circ} \mathrm{C}\right)$ & Acid $-\mathrm{H}_{2} \mathrm{SO}_{4}$ \\
\hline AC_H_4 & Ultrasonic-MW (300W)-Carbonize $\left(400^{\circ} \mathrm{C}\right)$ & Acid $-\mathrm{H}_{2} \mathrm{SO}_{4}$ \\
\hline AC_K_8 & Ultrasonic-MW (100W)-Carbonize $\left(800^{\circ} \mathrm{C}\right)$ & Base - KOH \\
\hline AC_K_4 & Ultrasonic-MW (100W)-Carbonize $\left(400^{\circ} \mathrm{C}\right)$ & Base - KOH \\
\hline AC_SO_8 & Ultrasonic-MW (100W)-Carbonize $\left(800^{\circ} \mathrm{C}\right)$ & Acid $-\mathrm{H}_{2} \mathrm{SO}_{4}$ \\
\hline AC_SO_4 & Ultrasonic-MW (100W)-Carbonize $\left(400^{\circ} \mathrm{C}\right)$ & Acid $-\mathrm{H}_{2} \mathrm{SO}_{4}$ \\
\hline
\end{tabular}

\section{Proximate analysis of precursor}

The raw material sample was characterized for proximate analysis by using American Society for Testing and Materials standard in order to determine the moisture content of bamboo (ASTM D 2867-99), the presence of volatile matter (ASTM D 5832-98), the ashes content (ASTM D 2866-94) and the amount of fixed carbon and waxes composition [7].

\section{Characterization of activated carbon}

Brunauer, Emmett, Teller (BET) test (Xyracorp, Autosorb-1, Malaysia) was used in order to determine the specific surface area of a variety materials by the BET Nitrogen adsorption technique. The adsorption process handled in 1 hour by using quick single point and multipoint particular BET surface area determinations.

Field Emission Scanning Electron Microscope (FESEM) was carried out using Carl Zeiss, Supra 40VP, Germany in conducive to examine the morphology of the sample and to analyze the composition, distribution and phase structure of residual bamboo. The sample must be electrically connected to the sample holder in order to prevent charging and distortion of the image.

Fourier Transform Infrared Spectroscopy (FTIR) (Perkin Elmer, Spectrum One-FTIR, USA) was performed in order to identify chemical bonds in a molecule by producing an infrared absorption spectrum for functional group classification. FTIR creates the absorbance spectra representing the unique chemical bonds and the molecular structure of the sample material. FTIR spectra were recorded between 4000 and $500 \mathrm{~cm}^{-1}$ by using AVATAR 360 Spectrophotometer.

\section{Determination of surface area and pore size}

\section{Results and Discussion}

Table 2 shows the total of active surface area and total pore volume analyzed using nitrogen adsorption/desorption. The acquired results determined the surface of the chemical activation with base, $\mathrm{KOH}$ consist a greater surface area as well as pore volume as compared with chemical activation using acid activating agent, $\mathrm{H}_{2} \mathrm{SO}_{4}$. The carbonization of bamboo at $800{ }^{\circ} \mathrm{C}$ gave a higher active surface area then carbonization at $400{ }^{\circ} \mathrm{C}$. The highest of active surface area obtained was $1162.73 \mathrm{~m}^{2} / \mathrm{g}$ with total pore value $0.7237 \mathrm{~cm}^{3} / \mathrm{g}$ using $300 \mathrm{~W}$ of MW-ultrasonic radiation power. The active surface area obtain from the study was compare with previous research on AC derived from different agricultural waste and tabulated in Table 3. The result indicated that present study gave highest $\mathrm{V}_{\text {mic }}$ and active surface area is at the power with another $\mathrm{AC}$ using $\mathrm{KOH}$ as activating agent. This comparison showed bamboo is one of the efficient and effective precursor in produce a high of $\mathrm{V}_{\text {mic }}$ carbon. 
Norakmalah et al: CHARACTERIZATION OF ACTIVATED CARBON USING CHEMICAL ACTIVATION

VIA MICROWAVE ULTRASONIC SYSTEM

Table 2. Chemical properties of produced activated carbon

\begin{tabular}{lcc}
\hline Experiment & $\begin{array}{c}\text { Active Surface Area } \\
\left(\mathbf{m}^{\mathbf{2}} / \mathbf{g}\right)\end{array}$ & $\begin{array}{c}\text { Total Pore Volume } \\
\left(\mathbf{c m}^{\mathbf{3}} \mathbf{g}\right)\end{array}$ \\
\hline AC_OH_8 & 1162.73 & 0.7237 \\
AC_OH_4 & 2.8791 & 0.0024 \\
AC_H_8 & 740.09 & 0.4019 \\
AC_H_4 & 478.14 & 0.2262 \\
AC_K_8 & 24.6062 & 0.0172 \\
AC_K_4 & 1.8299 & 00063 \\
AC_SO_8 & - & 0.0066 \\
AC_SO_4 & 4.7868 & 0.0078 \\
\hline
\end{tabular}

Table 3. Pore structure from other agricultural wastes by $\mathrm{MW}$ with $\mathrm{KOH}$ activation

\begin{tabular}{lcccl}
\hline Precursor & Power $(\mathbf{W})$ & $\mathbf{S}_{\text {BET }}\left(\mathbf{m}^{2} / \mathbf{g}\right)$ & $\mathbf{V}_{\text {mic }}\left(\mathbf{c m}^{3} / \mathbf{g}\right)$ & Ref \\
\hline Bamboo & 300 & 1162.73 & 0.7237 & This work \\
Oil palm fiber & 600 & 1223.00 & 0.4200 & {$[8]$} \\
Coconut husk & 600 & 1356.30 & 0.3920 & {$[9]$} \\
Pineapple & 600 & 1006.00 & 0.2800 & {$[10]$} \\
Siris seed pods & 620 & 1824.80 & 0.6450 & {$[11]$} \\
\hline
\end{tabular}

\section{Proximate analysis}

Table 4 show the properties of raw bamboo precursor. Before undergoes the proximate analysis, raw bamboo has been dried into oven for $30 \mathrm{~min}(\mathrm{BamP})$ and $15 \mathrm{~min}(\mathrm{BamPr})$ of temperature in order to remove impurities and water content. From the results, it showed that BamP consist of low moisture content when compared to BamPr. For volatile and ash content, sample BamP gave a higher value which is $45.320 \%$ and $1.98 \%$ while BamPr sample obtain $40.178 \%$ of volatile content and $1.5 \%$ of ash content. For fixed carbon content BamPr sample have $58.322 \%$ whereas BamP consist of $52.7 \%$ of fixed carbon. High ash content is undesired in AC processing because it represents amount of inorganic material from the precursor activation and a numerous treatment needed to be take place [12].

Table 4. Proximate of raw bamboo precursor

\begin{tabular}{lcccc}
\hline Experiment & $\begin{array}{c}\text { Moisture Content } \\
(\mathbf{\%})\end{array}$ & $\begin{array}{c}\text { Volatile Content } \\
\mathbf{( \% )}\end{array}$ & $\begin{array}{c}\text { Ash Content } \\
(\mathbf{\%})\end{array}$ & $\begin{array}{c}\text { Fixed Carbon } \\
\mathbf{( \% )}\end{array}$ \\
\hline $\mathrm{BamP}$ & 13.300 & 45.320 & 1.98 & 52.7 \\
$\mathrm{BamPr}$ & 14.356 & 40.178 & 1.5 & 58.322 \\
\hline
\end{tabular}

\section{Elemental analysis (CHNS-O analysis)}

Table 5 summarizes the results of elemental analysis which gave the percentage of carbon, hydrogen, nitrogen and sulphur present in the sample. The result indicated that the largest elements inside activated carbon are oxygen and carbon. With increment of activation temperature, there was decreasing in carbon content which probably due to the discharge of volatiles [13]. In chemical activation of acid activating agent, $\mathrm{H}_{2} \mathrm{SO}_{4}$ the activation process has 
provoked a progress of discharge oxygen with notable loss at $800{ }^{\circ} \mathrm{C}$. Discharge of oxygen happened because element of oxygen intimate the fraction of oxygen content was not located around the pore entry of activated carbon [14]. High of moisture and volatile content also give a higher value for oxygen element. On the contrary, there was a decreasing of carbon content in a higher temperature. Besides that, there was a reduction of hydrogen element at a temperature $800^{\circ} \mathrm{C}$. The percentages of carbon significantly high at temperature $400{ }^{\circ} \mathrm{C}$ with radiation power $300 \mathrm{~W}$ and $100 \mathrm{~W}$ based on different type of activating agent. The precursor of carbon could barely be heated without impregnation of activation agent, demonstrating that activation agent acted as the fundamental MW absorber at the primary stage. With the evolution of pore structure, the AC itself could acquire MW energy [15]. At low microwave energy, the pore structure was not satisfactorily created which improved with the expanding of microwave power. Nevertheless, at tremendous radiation power, absorbed MW energy eclipse at some of power so that the overfull energy keep create a small feature of carbon burnt and the structure was destroyed [16].

Table 5. Result of elemental analysis

\begin{tabular}{lccccc}
\hline Experiment & $\begin{array}{c}\text { Carbon } \\
(\mathbf{\%})\end{array}$ & $\begin{array}{c}\text { Hydrogen } \\
(\mathbf{\%})\end{array}$ & $\begin{array}{c}\text { Nitrogen } \\
(\mathbf{\% )}\end{array}$ & $\begin{array}{c}\text { Sulphur } \\
\mathbf{( \% )}\end{array}$ & $\begin{array}{c}\text { Oxygen } \\
(\mathbf{\%})\end{array}$ \\
\hline AC_OH_4 & 30.3338 & 2.5647 & 0.4022 & 0.0000 & 66.6993 \\
AC_H_4 & 37.5033 & 0.8403 & 0.2574 & 0.0386 & 61.3604 \\
AC_OH_8 & 20.5301 & 1.8585 & 1.1981 & 0.0000 & 76.4133 \\
AC_H_8 & 14.0534 & 0.1058 & 0.399 & 0.0167 & 85.4251 \\
AC_K_4 & 28.5147 & 2.4452 & 0.380 & 0.0130 & 68.6471 \\
AC_SO_4 & 26.2542 & 1.8933 & 0.149 & 0.0000 & 71.7035 \\
AC_K_8 & 21.4699 & 0.6440 & 0.412 & 0.0471 & 77.4270 \\
AC_SO_8 & 20.7577 & 0.7182 & 0.466 & 0.0000 & 78.0581 \\
\hline
\end{tabular}

\section{FTIR analysis}

The prepared activated carbon was analyzed for functional group using FTIR shown a following bands: 3308.78 $\mathrm{cm}^{-1}$ was attributed to $\mathrm{O}-\mathrm{H}$ vibration in hydroxyl groups. The location of hydrogen bonded $\mathrm{OH}$ groups usually at range $3200-3750 \mathrm{~cm}^{-1}$ for alcohol and phenol which involve in hydrogen bonding may be due to adsorbed water [17], $\mathrm{C}=\mathrm{C}$ stretching vibration of aromatic rings at $1599.98 \mathrm{~cm}^{-1}$, the relatively intense band at $1031.89 \mathrm{~cm}^{-1}$ can be assigned to alcohol or phenol groups of $\mathrm{R}-\mathrm{OH}, 1234.05 \mathrm{~cm}^{-1}$ with absence of $\mathrm{C}=\mathrm{O}$ stretching from the esters $(\mathrm{C}-\mathrm{O})$ of strong intensity absorptions. Figure 1 shown band at range $756-540 \mathrm{~cm}^{-1}$ with $667.07 \mathrm{~cm}^{-1}$ is $(\mathrm{C}-\mathrm{O}-\mathrm{H})$ twist abroad with strong aliphatic, $1350.48 \mathrm{~cm}^{-1}$ of amines compound occurs which correlated out of plane bending absorption, alkanes $\left(\mathrm{C}-\mathrm{H} \mathrm{CH}_{2}\right)$ found at range of $1457.03 \mathrm{~cm}^{-1}$ bending absorption of methylene groups and 1784.93 $\mathrm{cm}^{-1}$ denotes $\mathrm{C}=\mathrm{O}$ stretching from ketones $(\mathrm{C}=\mathrm{OR})$, aldehyde $(\mathrm{C}=\mathrm{OH})$ and carboxylic acid $(\mathrm{COOH})$. Some weak bands also appeared in the range of $600-900 \mathrm{~cm}^{-1}$ which associated with out-of-plane bending mode of $(\mathrm{C}-\mathrm{H})$ and $\mathrm{O}-\mathrm{H}$ group. Heating at a high of temperature make some of peaks disappear in AC_K_8 and AC_H_8. The main surface functional groups present on the activated carbon of bamboo are lactones, ketones, carboxylic anhydrides, quinine structure and aromatic ring [18].

\section{Activated carbon morphology}

Figure 2 indicates the FESEM images of the raw bamboo and derived AC. There was no pore development on the precursor of raw bamboo residual and the structure of the surface is rough and uneven. From Figure 1a, many large pores shape and size were clearly found on the AC surface after the activation process of MW-ultrasonic and chemical activation. The well-developed pores had led to the large surface area and porous structure of the activated carbon had shown in Figure 1c and 1d. It can be seen that there was a significant difference between sample from $\mathrm{KOH}$ and $\mathrm{H}_{2} \mathrm{SO}_{4}$ surface texture. Pore development was caused by the breakdown of some material in the precursor due to thermal expansion during the activation step [19]. The reaction rate between the activating agent which is $\mathrm{KOH}$ and carbon also increase when the precursor is subjected to high activation temperature, thus leading to the formation of well-developed pores [20]. 


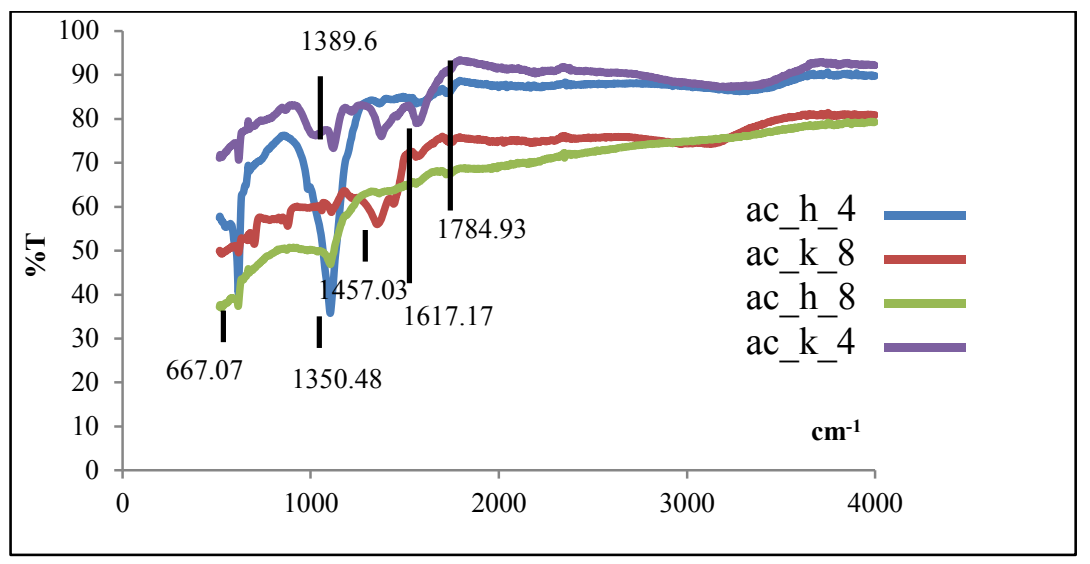

Figure 1. FTIR Spectra of activated carbon

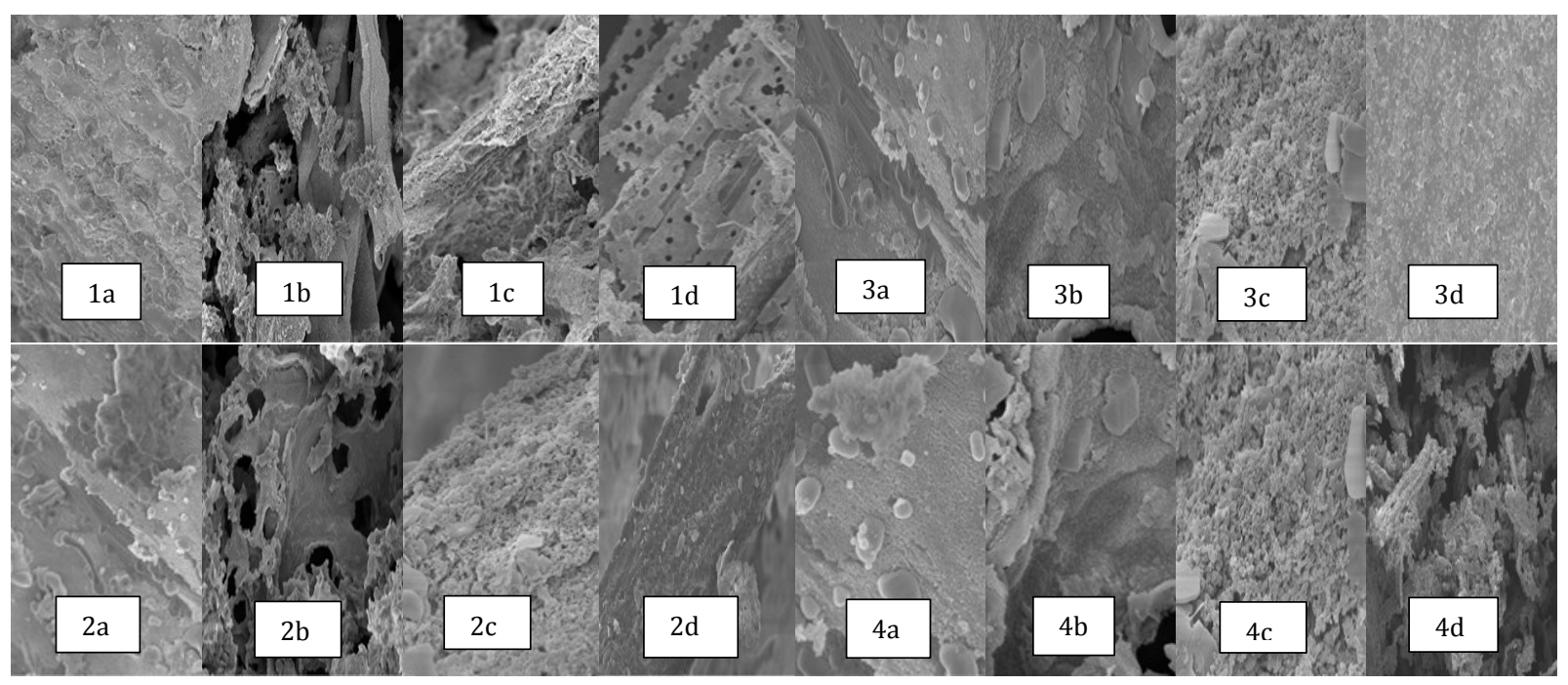

Figure 2. FESEM Mag. $1.00 \mathrm{~K}$ and 5.00K (1a \& 2a) AC_H_4a; $(1 \mathrm{~b} \& 2 \mathrm{~b})$ AC_H_4b; (1c \& 2c) AC_K_4; (1d \&

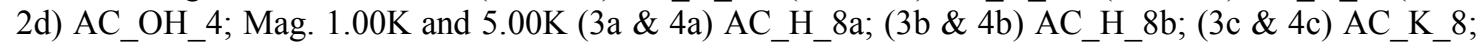
$(3 \mathrm{~d} \& 4 \overline{\mathrm{d}})$ AC $\_$OH_8

\section{Conclusion}

The present investigation showed that bamboo is a promising precursor to be used in the preparation of activated carbon. In the view of experiment results, the best activated carbon properties of the sample prepared from the bamboo raw material by a one-step chemical activation with base activating agent, $\mathrm{KOH}$ with $\mathrm{MW}$-ultrasonic radiation power $300 \mathrm{~W}$ were obtained at the carbonization temperature of $800{ }^{\circ} \mathrm{C}$ with the highest of surface area, $1162.73 \mathrm{~m}^{2} / \mathrm{g}$. The active surface area of the bamboo activated carbon derived in this work was considered relatively high besides being mesopores. The result proved that the potentially of MW-ultrasonic activation was rapid, efficient and feasible as a viable activation method.

\section{Acknowledgement}

The present research was made possible through a Research Acculturation Colloborative Effort (RACE) by Universiti Teknologi MARA (600-RMI/RACE 16/6/2 (9/2012)) and also facilities and constant encouragement from Faculty of Chemical Engineering, Universiti Teknologi MARA is gratefully acknowledged. 


\section{References}

1. Chen, D., Zhou, J. and Zhang, Q. (2014). Effects of heating rate on slow pyrolysis behavior, kinetic parameters and products properties of moso bamboo. Bioresource Technology, 169 (9): $313-319$.

2. Liu, Q.-S., Zheng, T., Wang, P. and Guo, L. (2010). Preparation and characterization of activated carbon from bamboo by microwave-induced phosphoric acid activation. Industrial Crops and Products, 31(2): 233 - 238.

3. Wang, R., Amano, Y. and Machida, M. (2013). Surface properties and water vapor adsorption-desorption characteristics of bamboo-based activated carbon. Journal of Analytical and Applied Pyrolysis, 104: 667 - 674.

4. Lee, Y. J., Kim, G.-P., Bang, Y., Yi, J., Seo, J. G. and Song, I. K. (2014). Activated carbon aerogel containing graphene as electrode material for supercapacitor. Materials Research Bulletin, 50: 240 -245.

5. Iqbaldin, M. N. M., Khudzir, I., Azlan, M. I. M., Zaidi, A. G., Surani, B. and Zubri, Z. (2013). Properties of Coconut Shell Activated Carbon. Journal of Tropical Forest Science, 25 (4): 497 - 503.

6. Dabrowski, A., Podkościelny, P., Hubicki, Z. and Barczak, M. (2005). Adsorption of phenolic compounds by activated carbon- a critical review. Chemosphere, 58 (8):1049 - 1070.

7. Gonzalez, P. G. and Pliego-Cuervo, Y. B. (2013). Physicochemical and microtextural characterization of activated carbons produced from water steam activation of three bamboo species. Journal of Analytical and Applied Pyrolysis, 99: 32 - 39.

8. Foo, K.Y. and Hameed, B. H. (2012) Adsorption characteristics of industrial solid waste derived activated carbon prepared by microwave heating for methylene blue. Fuel Processing Technology, 99-103.

9. Foo, K. Y. and Hameed, B. H. (2012). Coconut husk derived activated carbon via microwave induced activation: effects of activation agents, preparation parameters, and adsorption performance. Chemical Engineering Journal, 184: 57 - 65.

10. Foo, K. Y. and Hameed, B. H. (2012). Porous structure and adsorptive properties of pineapple based activated carbons prepared via microwave assisted $\mathrm{KOH}$ and $\mathrm{K}_{2} \mathrm{CO}_{3}$ activation. Microporous and Mesoporous Materials, 148: $191-195$.

11. Ahmed, M. J. and Theydan, S. K. (2013). Microporous activated carbon from Siris seed pods by microwaveinduced KOH activation for metronidazole adsorption. Journal of Analytical and Applied Pyrolysis, 99: 101 109.

12. Koplan, S., Okun, D. T., Hillman, J. A., Lane, C. R., Pearson, D. R. and Aranoff, S. L. (2006). Certain activated carbon from China. U.S International Trade Commission. Washington.

13. Ma, X., Yang, H., Yu, L., Chen, Y. and Li, Y. (2014). Preparation, surface and pore structure of high surface area activated carbon fibers from bamboo by steam activation. Materials, 7(6): $4431-4441$.

14. Paiva, M. C. R., Bernardo, C. A. and Nardin, M. (2000). Mechanical, surface and interfacial characteristic of pitch and PAN-carbon fibres. Carbon, 38: $1323-1327$.

15. Wang, T. H., Tan, S. X. and Liang, C. H. (2009). Preparation and characterization of activated carbon from wood via microwave-induced $\mathrm{ZnCl}_{2}$ activation. Carbon, 47: 1880 - 1883.

16. Deng, H., Li, G., Yang, H., Tang, J. and Tang, J. (2010). Preparation of activated carbons from cotton stalk by microwave assisted $\mathrm{KOH}$ and $\mathrm{K}_{2} \mathrm{CO}_{3}$ activation. Chemical Engineering Journal, 163 (3): 373 - 381.

17. Ahmad, A. A. and Hameed, B. H. (2009). Reduction of COD and color of dyeing effluent from a cotton textile mill by adsorption onto bamboo-based activated carbon. Journal of Hazardous Materials, 172 (2-3): 1538 1543.

18. Ahmad, M. A., Ahmad Puad, N. A. and Bello, O. S. (2014). Kinetic, equilibrium and thermodynamic studies of synthetic dye removal using pomegranate peel activated carbon prepared by microwave-induced $\mathrm{KOH}$ activation. Water Resources and Industry, 6: $18-35$.

19. Nazri, I., Ahmad, Z. A., Ahmad, M. A., Ahmad, N. and Sulaiman, S. K. (2010). Optimization of process variables for malachite green dye removal using rubber seed coat based activated carbon. International Journal of Engineering and Technology, 11: $305-311$.

20. Sun, Y. and Webley, P. A. (2010). Preparation of activated carbons from corncob with large specific surface area by a variety of chemical activators and their application in gas storage. Chemical Engineering Journal, 162: $883-892$. 